\title{
PENGARUH PENGGUNAAN BAHAN BAKAR PREMIUM DAN PERTALITE TERHADAP EMISI GAS BUANG SEPEDA MOTOR EMPAT TAK SATU SILINDER 108 CC
}

\author{
Kurnia Dwi Artika, Rudiansyah \\ Jurusan Mesin Otomotif, Politeknik Negeri Tanah Laut \\ Jl. A Yani Km 6 Pelaihari Tanah Laut Kalimantan Selatan \\ Telp. (0512) 21537, Faks. (0512) 21537 \\ E-mail: kurnia_2a@yahoo.co.id
}

Naskah diterima: 02 Desember 2017 ; Naskah disetujui: 25 Desember 2017

\begin{abstract}
ABSTRAK
Kontribusi emisi gas buang sepeda motor sebagai sumber polusi udara sebesar 60-70\%, sangat memberi pengaruh terhadap kehidupan. Seiring dengan meningkatnya volume kendaraan sepeda motor yang menambah parah permasalahan polusi dan kemacetan baik di desa maupun di ibukota. Salah satu langkah alternative untuk mengatasi permasalahan tingkat polusi udara yaitu dengan menggunakan bahan bakar yang lebih ramah lingkungan. Meski dari segi harga relatif lebih mahal, namun dapat mengurangi dampak pencemaran lingkungan. Penelitian ini bertujuan untuk mengetahui dan menganalisa pengaruh penggunaan bahan bakar premium dan pertalite terhadap karakteristik dari emisi gas buang yang terkandung ( $\left.\mathrm{HC}, \mathrm{CO}, \mathrm{CO}_{2}, \lambda\right)$ dengan menggunakan sepeda Motor Honda Beat 108 cc pada tiga variasi tahun pembuatan yaitu tahun 2010, 2011, dan 2012. Hasil penelitian menunjukkan adanya peningkatan kualitas emisi gas buang pertalite sebesar $18 \%$ lebih baik dari pada penggunaan bahan bakar premium, dan hasil ini masih berada di bawah nilai ambang batas emisi gas buang kendaraan berdasarkan keputusan Menteri Lingkungan Hidup Nomor 05 Tahun 2006.
\end{abstract}

Kata Kunci: Emisi Gas Buang, premium, pertalite, Automotive Gas Analyzer

\section{PENDAHULUAN}

Tingkat pertumbuhan kendaraan bermotor yang tinggi, di satu sisi dapat mendorong tingkat pertumbuhan ekonomi, akan tetapi di sisi lain dapat menimbulkan dampak lingkungan yang sangat serius. Dampak lingkungan yang ditimbulkan diantaranya kemacetan, kebisingan hingga pencemaran atau polusi udara yang diakibatkan oleh emisi gas buang yang dihasilkan oleh mesin kendaraan bermotor. Saat ini emisi gas buang hasil pembakaran mesin kendaraan bermotor merupakan faktor penyebab polusi yang paling dominan, terutama di kota-kota besar.

Hasil penelitian menunjukkan bahwa kontribusi pencemaran udara yang berasal dari sektor transportasi mencapai $60 \%$, selebihnya sektor industry $25 \%$, rumah tangga $10 \%$ dan sampah $5 \%$ [1]. Hasil studi juga menunjukkan bahwa bahan pencemar udara di kotakota besar seperti karbonmonoksida (CO), hidrokarbon (HC), ozon (O3) dan partikulat telah melampaui ambang batas baku mutu udara. Kondisi di atas tentu sangat menghawatirkan, karena emisi gas buang yang dihasilkan akan terus mengalami peningkatan seiring dengan laju pertumbuhan kendaraan bermotor. Oleh karena itu polusi udara yang ditimbulkan oleh emisi gas buang ini harus segera dikendalikan mengingat di dalam gas buang kendaraan bermotor banyak mengandung senyawa kimia yang berbahaya bagi manusia. Beberapa senyawa yang dinyatakan dapat membahayakan kesehatan manusia adalah oksida sulfur (SOx) oksida nitrogen (NOx), oksida karbon (COx), hidrokarbon $(\mathrm{HC})$, logam berat tertentu $(\mathrm{Pb})$ dan partikulat.

Dampak yang ditimbulkan dapat berupa gangguan saluran pernafasan, gangguan organ dalam seperti paru-paru hati dan lainnya, gangguan syaraf, gangguan reproduksi, menurunkan kecerdasan pada anak serta dapat menimbulkan kematian. Pada dasarnya jenis bahan pencemar yang dikeluarkan semua jenis kendaraan adalah sama hanya komposisinya saja yang berbeda karena adanya perbedaan kondisi dan sistem operasi antara mesin kendaraan yang satu dengan yang lainnya.

Mesin kendaraan terbaru umumnya memiliki emisi gas buang dengan kadar yang lebih rendah dibandingkan dengan mesin kendaraan yang lebih tua umurnya, hal ini dikarenakan adanya kesadaran masyarakat akan pencemaran udara akibat emisi gas buang kendaraan yang semakin tinggi. 
Dan adanya peraturan yang lebih tegas mengenai batasan emisi gas buang bagi kendaraan baru sehingga mampu mendorong industri untuk memproduksi kendaraan bermotor yang lebih ramah lingkungan serta menerapkan standar ekonom dalam pengisian bahan bakar. Berdasarka latar belakang di atas, maka dalam penelitian ini akan dilakukan investigasi terhadap emisi gas buang kendaraan kususnya yang bermesin bensin dari berbagai merek kendaraan pada berbagai tahun pembuatan. Senyawa kimia dari emisi gas buang yang dikaji adalah karbonmonoksida (CO) dan hidrokarbon (HC), karena kedua senyawa berdampak langsung bagi kesehatan manusia.

\section{TINJAUAN PUSTAKA}

\section{Motor Bakar}

Motor bakar adalah suatu jenis mesin penggerak dengan memanfaatkan proses pembakaran yang mengubah energi kalor menjadi energi mekanik [2].

Motor bakar dibagi menjadi dua jenis, yaitu motor pembakaran dalam dan pembakaran luar, proses pembakaran dalam terjadi di dalam motor bakar itu sendiri, dan motor pembakaran luar, yaitu memperoleh energi dari proses pembakaran luar.

Piston pada sepeda motor empat tak harus melakukan empat langkah untuk mendapatkan tenaga melalui proses pembakaran. Empat langkah tersebut yaitu langkah hisap, langkah kompresi, langkah usaha, dan langkah buang.

Adapun posisi dari setiap langkah adalah seperti pada Gambar 1 berikut ini.

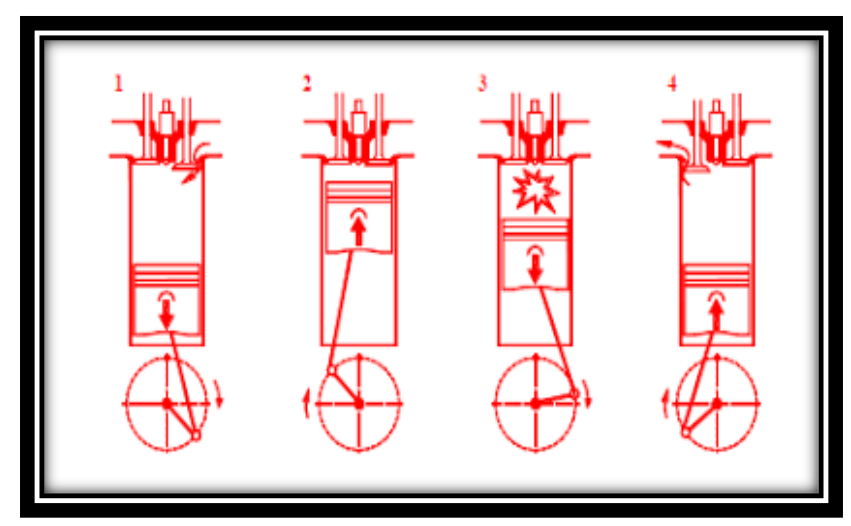

Gambar 1 Prinsip Kerja Empat Langkah berikut:

Adapun penjelasan dari Gambar 1 adalah sebagai

a. Langkah hisap yaitu ketika piston bergerak dari TMA ke TMB, katup hisap membuka dan katup buang menutup. Kondisi ini menyebabkan volume ruang bakar dan kevakuman meningkat, sehingga tekanan di dalam silinder menurun. Bahan bakar secara otomatis akan terhisap menuju ruang silinder karena kevakuman tersebut. b. Langkah kompresi yaitu campuran bahan bakar sudah masuk ke ruang silinder, piston bergerak, dari TMB ke TMA, katup hisap dan katup buang menutup, campuran bahan bakar terkompresi. Penyempitan ruangan yang terjadi pada langkah ini menyebabkan tekanan dan suhu meningkat. Mendekati langkah akhir kompresi, busi memercikan bunga api dan terjadilah pembakaran.

c. Langkah usaha yaitu ketika bahan bakar yang terkompresi dibakar oleh percikan bunga api yang dihasilkan dari busi, katup hisap dan katup buang masih menutup. Meledaknya bahan bakar karena percikan bunga api dari busi menyebabkan tekanan dan suhu meningkat drastis. Torak terdorong oleh tekanan tersebut menuju TMB menghasilkan gaya dorong untuk memutar poros engkol.

d. Langkah buang yaitu piston bergerak dari TMB ke TMA, ktup hisap menutup dan katup buang membuka, gas buang terdorong keluar oleh gerakan piston.

\section{Bahan Bakar}

Bahan bakar adalah suatu materi apa saja yang bisa dirubah menjadi energi. Berdasarkan bentuknya, ada bahan bakar padat, bahan bakar cair dan bahan bakar gas. Sedangkan menurut asalnya, bahan bakar dibagi menjadi bahan bakar nabati, bahan bakar mineral, dan bahan bakar fosil.

\section{a. Premium}

Premium merupakan bahan bakar minyak jenis distilat berwarna kuning jernih, warna tersebut akibat adanya zat pewarna tambahan (dye) [3].

Adapun rumus kimia untuk pembakaran pada bensin premium dengan oksigen adalah sebagai berikut:

$$
\mathrm{C} 8 \mathrm{H} 18+12,5 \mathrm{O} 2 \rightarrow 8 \mathrm{CO} 2+9 \mathrm{H} 2 \mathrm{O}
$$

Pembakaran di atas diasumsikan semua bensin terbakar dengan sempurna.

\section{b. Pertalite}

Pertalite adalah bahan bakar minyak dari pertamina dengan RON 90. Pertalite dihasilkan dengan penambahan zat aditif dalam proses pengolahannya dikilang minyak. Selain itu, RON 90 membuat pembakaran pada mesin kendaraan dengan teknologi terkini lebih baik dibandingkan dengan premium yang memiliki RON 88.

Adapun perbedaan antara Premium dan Pertalite dalam berbagai segi seperti segi ekonomi, tingkat polutan, teknologi pembuatannya dan wujudnya adalah seperti pada Tabel 1 [4]. 
Tabel 1 Perbedaan Premium dengan Pertalite

\begin{tabular}{|c|c|c|c|c|}
\hline \multicolumn{5}{|c|}{ Premium } \\
\hline $\begin{array}{c}\text { Segi } \\
\text { teknologi }\end{array}$ & Segi Ekonomi & $\begin{array}{l}\text { Polusi yang } \\
\text { dihasilkan }\end{array}$ & $\begin{array}{c}\text { Segi } \\
\text { pembuatan }\end{array}$ & $\begin{array}{c}\text { Segi } \\
\text { wujud }\end{array}$ \\
\hline $\begin{array}{l}\text { Memiliki } \\
\text { RON } 88\end{array}$ & $\begin{array}{c}\text { Knocking } \\
\text { berkepanjanga, } \\
\text { mengakibatkan } \\
\text { kerusakan pada } \\
\text { piston sehingga } \\
\text { komponen } \\
\text { terebut lebih } \\
\text { cepat diganti }\end{array}$ & $\begin{array}{l}\text { Menghasilkan } \\
\text { NOx dan Cox } \\
\text { dalam jumlah } \\
\text { besar }\end{array}$ & $\begin{array}{c}\text { Pembuatannya } \\
\text { menggunakan } \\
\text { tambahan } \\
\text { pewarna (dye). } \\
\text { kandungan } \\
\text { sulfur } \\
\text { maksimal } \\
0,15 \% \mathrm{~m} / \mathrm{m} \\
\text { atau setara } \\
\text { dengan } 1500 \\
\text { ppm }\end{array}$ & $\begin{array}{c}\text { Berwarna } \\
\text { kuning } \\
\text { bening }\end{array}$ \\
\hline \multicolumn{5}{|c|}{ Pertalite } \\
\hline $\begin{array}{c}\text { Segi } \\
\text { teknologi }\end{array}$ & Segi Ekonomi & $\begin{array}{c}\text { Polusi yang } \\
\text { dihasilkan }\end{array}$ & $\begin{array}{c}\text { Segi } \\
\text { pembuatan }\end{array}$ & Segi wujud \\
\hline $\begin{array}{l}\text { Memiliki } \\
\text { RON } 90\end{array}$ & $\begin{array}{l}\text { Harga lebih } \\
\text { murah, lebih } \\
\text { bagus pada } \\
\text { mesin }\end{array}$ & $\begin{array}{l}\text { Menghasilkan } \\
\text { NOx dan Cox } \\
\text { dalam jumlah } \\
\text { sedikit }\end{array}$ & $\begin{array}{c}\text { Memiliki } \\
\text { kandungan } \\
\text { sulfur } \\
\text { maksimal } \\
0,05 \% \mathrm{~m} / \mathrm{m} \\
\text { atau setara } \\
\text { dengan } 500 \\
\text { ppm }\end{array}$ & $\begin{array}{l}\text { Berwarna } \\
\text { hijau terang }\end{array}$ \\
\hline
\end{tabular}

Nilai Ambang Batas Emisi Gas Buang Kendaraan Bermotor Sesuai Peraturan Pemerintah

Adapun regulasi yang mengatur tentang ambang batas ini melalui Peraturan Menteri Lingkungan Hidup Nomor 05 Tahun 2006, tentang Ambang Batas Emisi Gas Buang Kendaraan Bermotor Lama menjelaskan Ambang Batas Emisi Gas Buang Kendaraan Bermotor Lama sebagai berikut.

Tabel 2 Ambang Batas Emisi Gas Buang Kendaraan Bermotor Lama.

\begin{tabular}{|c|c|c|c|c|}
\hline Kategori & $\begin{array}{c}\text { Tahun } \\
\text { Pembuatan }\end{array}$ & \multicolumn{2}{|c|}{ Parameter } & \multirow{2}{*}{$\begin{array}{c}\text { Metode } \\
\text { Uji }\end{array}$} \\
\cline { 3 - 4 } & & $\begin{array}{c}\mathrm{CO} \\
(\%)\end{array}$ & $\begin{array}{c}\mathrm{HC} \\
(\mathrm{ppm})\end{array}$ & \\
\hline $\begin{array}{c}\text { Sepeda } \\
\text { motor }\end{array}$ & $<2010$ & 4,5 & 12000 & Idle \\
2 langkah & & 5,5 & 2400 & Idle \\
\hline $\begin{array}{c}\text { Sepeda } \\
\text { motor }\end{array}$ & $<2010$ & & & \\
\hline \begin{tabular}{c}
4 langkah \\
\hline
\end{tabular} & & & & \\
\hline
\end{tabular}

\begin{tabular}{|c|l|l|l|l|}
\hline Sepeda & $\geq 2010$ & 4,5 & 200 & Idle \\
motor (2 & & & & \\
langkah & & & & \\
dan 4 & & & & \\
langkah) & & & & \\
\hline
\end{tabular}

Sumber : [7]

\section{Emisi Gas buang}

Emisi gas buang kendaraan adalah sisa hasil pembakaran bahan bakar didalam mesin kendaraan yang dikeluarkan melalui sistem pembuangan mesin, sedangkan proses pembakaran adalah reaksi kimia antara oksigen di dalam udara dengan senyawa hidrokarbon di dalam bahan bakar untuk menghasilkan tenaga. Dalam reaksi yang sempurna, makasisa hasil pembakaran adalah berupa gas buang yang mengandung karbondioksida $\left(\mathrm{CO}_{2}\right)$, uap air $\left(\mathrm{H}_{2} \mathrm{O}\right)$, Oksigen $\left(\mathrm{O}_{2}\right)$ dan Nitrogen $\left(\mathrm{N}_{2}\right)$. Dalam prakteknya, pembakaran yang terjadi di dalam mesin kendaraan tidak selalu berjalan sempurna sehingga di dalam gas buang mengandung senyawa berbahaya seperti karbonmonoksida (CO), hidrokarbon (HC), Nitrogenoksida (NOx) dan partikulat.

Di samping itu untuk bahan bakar yang mengandung timbal dan sulfur, hasil pembakaran di dalam mesin kendaraan juga akan menghasilkan gas buang yang mengandung sulfurdioksida $\left(\mathrm{SO}_{2}\right)$ dan logam berat (Pb) [5].

\section{Teori Pembentukan CO dan HC pada Emisi Gas Buang}

Bahan bakar akan habis terbakar jika pembakaran terjadi secara sempurna, namun hal ini sangat sulit dicapai karena kondisi mesin di lapangan yang senantiasa mengalami perubahan. Pembakaran yang tidak sempurna melepaskan hidrokarbon yang tidak terbakar dan juga menghasilkan $\mathrm{CO}$ yang berbahaya bagi kesehatan. Kadar HC yang tinggi pada emisi dapat disebabkan oleh campuran yang kaya, biasanya terjadi pada putaran mesin rendah. Pada putaran rendah, saat pengapian cenderung dimundurkan sehingga pembakaran terlambat menyebabkan ada sebagian bahan bakar tidak terbakar. Bentuk ruang bakar yang rumit akan sulit dijangkau oleh api pembakaran, menyebabkan bahan bakar pada daerah tersebut sulit terbakar. Bahan bakar yang tidak terbakar akan keluar bersama gas buang sehingga konsentrasi HC menjadi tinggi.

Kadar CO yang tinggi pada emisi juga dapat disebabkan oleh campuran yang kaya, yang terjadi pada putaran mesin rendah, karena pada putaran rendah, saat pengapian cenderung dimundurkan sehingga pembakaran terlambat yang menyebabkan sebagian unsur $\mathrm{C}$ dan $\mathrm{O}$ tidak berubah menjadi $\mathrm{CO}_{2}$. Rendahnya temperatur pembakaran juga menyebabkan reaksi pembakaran tidak mampu mengubah unsur $\mathrm{C}$ dan $\mathrm{O}$ menjadi $\mathrm{CO}_{2}$, karena suhu yang dibutuhkan untuk membentuk $\mathrm{CO}_{2}$ lebih besar dari pada pembentukan $\mathrm{CO}$ yang menyebabkan emisi mengandung kadar $\mathrm{CO}$ yang tinggi. 
Salah satu yang mempengaruhi kandungan emisi gas buang adalah kualitas pembakaran yang ditentukan salah satunya oleh kualitas campuran udara dengan bahan bakar. Istilah untuk menyebutkan perbandingan campuran antara udara dan bahan bakar yang digunakan untuk proses pembakaran biasa disebut Air Fuel Ratio (AFR). Secara teori, AFR ideal untuk bahan bakar bensin adalah 14,7:1, artinya untuk membakar 1 gram bensin dibutuhkan 14,7 gram udara. Kenyataan di lapangan terkadang tidak selalu sesuai dengan teori. Untuk membandingkan antara kondisi nyata dengan teori, dirumuskan suatu perhitungan yang disebut dengan istilah lambda $(\lambda)$, jika jumlah udara yang tersedia untuk pembakaran sesuai dengan teori $(\lambda=1)$, berarti campuran tersebut ideal, memungkinkan pembakaran terjadi sempurna. Selain jumlah udara, untuk membantu tercapainya pembakaran yang baik adalah dengan kualitas bahan bakar yang baik [2].

Kondisi lingkungan yang sangat memprihatinkan memaksa pemerintah juga mengeluarkan peraturan tentang standar kualitas udara yang mengacu pada Peraturan Pemerintah Republik Indonesia No. 41 tahun 1999 tentang standar kualitas udara ambien adalah seperti ditunjukkan pada Tabel 3 [6].

Tabel 3 Standar Kualitas Udara Ambient.

\begin{tabular}{|c|c|}
\hline Parameter & Baku Mutu yang Diperkenankan \\
\hline Nox & $0,05 \mathrm{ppm} / 24 \mathrm{jam}$ \\
CO & $20 \mathrm{ppm} / 8 \mathrm{jam}$ \\
$\mathrm{SOx}$ & $0,10 \mathrm{ppm} / 24 \mathrm{jam}$ \\
O3 & $0,10 \mathrm{ppm} / 24 \mathrm{jam}$ \\
$\mathrm{SPM} 10$ & $100 \mathrm{ppm} / 24 \mathrm{jam}$ \\
$\mathrm{HC}$ & $0,24 \mathrm{ppm} / 3 \mathrm{jam}$ \\
\hline
\end{tabular}

\section{AFR (Air Fuel Ratio)}

Air Fuel Ratio adalah perbandinganudara dan bahan bakar (bensin) yang masuk ke dalam ruang bakar mesin. Teori stoikiometri menyatakan AFR yang ideal adalah 14,7:1, artinya untuk membakar 1 gram bensin dibutuhkan 14,7 gram udara untuk menghasilkan pembakaran yang sempurna. AFR yang terbentuk tidak selalu secara teoritis, karena pada kenyataannya mesin bekerja pada kondisi yang tidak konstan tergantung beban yang dibawa oleh mesin [8].

Untuk menghitung seberapa besar penyimpangan jumlah udara dalam campuran dibandingkan dengan kebutuhan secara teori dirumuskan suatu perhitungan yang disebut dengan istiah Lambda. Secara sederhana, dirumuskan sebagai berikut:

$\lambda=\frac{\text { Jumlah udara sesungguhnya }}{\text { Jumlah udara sesuai stoikiometri }}$

Jika udara sesungguhnya 14,7, maka:

$$
\begin{aligned}
\lambda & =\frac{14,7}{14,7} \\
& =1,0
\end{aligned}
$$

Artinya:

$\lambda=1$, berarti campuran ideal, karena yang terjadi pada kondisi nyata tersebut sesuai dengan teori stoikiometri.

$\lambda>1$, berarti campuran kurus, udara yang dimasukkan lebih banyak dari kebutuhan teori.

$\lambda<1$, berarti campuran gemuk, udara yang dimasukkan kurang dari kebutuhan teori.

\section{METODOLOGI}

Sepeda motor Honda Beat dengan variasi tahun keluaran, yaitu Tahun 2010, 2011 dan 2012 dengan spesifikasi :

- Tipe mesin 4 langkah, SOHC.

- Sistem pendingin udara dan kipas.

- Volume langkah : 108 cc. (Diam.50 x 55 mm).

- Perbandingan kompresi : 9,2: 1 .

Adapun prosedur penelitian sebagai berikut :

1. Mempersiapkan alat dan bahan.

2. Menghidupkan mesin kurang lebih 5 menit, untuk mendapatkan suhu kurang lebih $(50-70){ }^{\circ} \mathrm{C}$.

3. Memasang alat uji emisi.

4. Pengujian dilakukan dengan menggunakan bahan bakar premium dan pertalite pada sepeda motor Honda Beat.

5. Mencetak hasil pengukuran uji emisi dan membuat tabel-grafik.

6. Menganalisa hasil dan menyimpulkan.

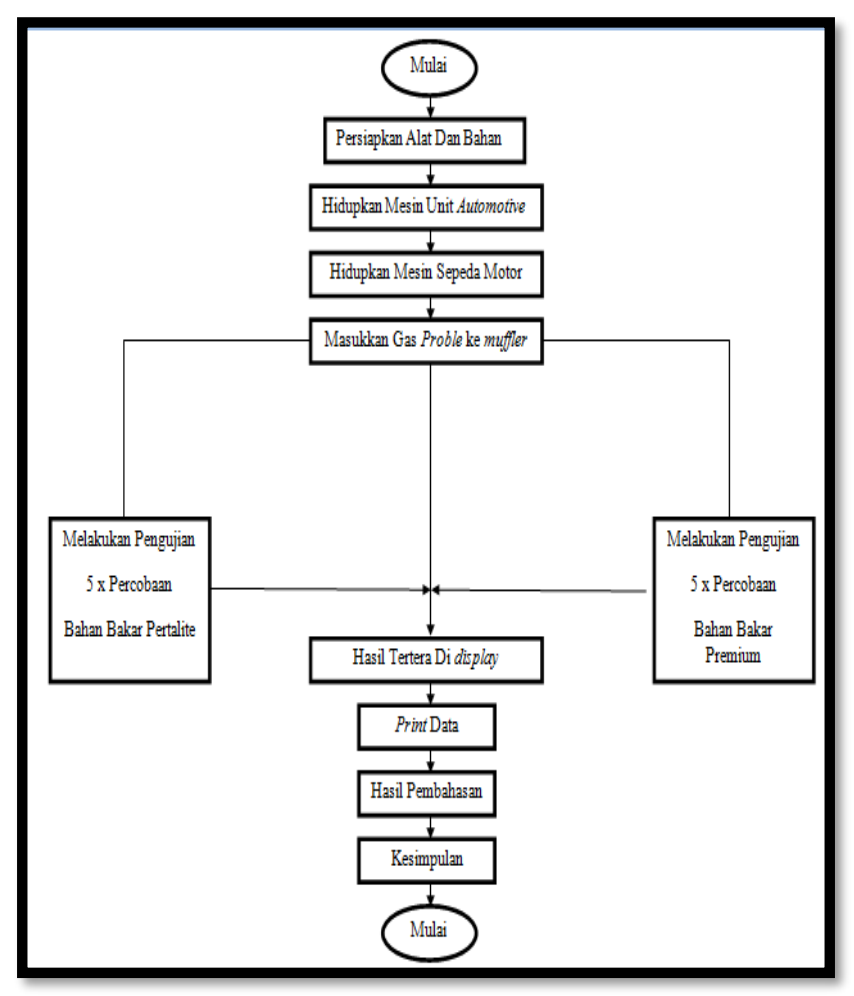

Gambar 2 Flowchart Penelitian 
Metode yang digunakan adalah dengan menghidupkan Blower, untuk menjaga mesin agar tidak terlalu panas pada saat pengujian off road/stand kendaraan sepeda motor Beat 110 CC..

Adapun alat uji emisi adalah menggunakan Automotive Gas Analyzer, untuk menguji kandungan emisi gas buang dengan spesifikasi, seperti pada Gambar 3:

- Merek KOENG

- Nomor seri KEG-500

- Power : $110 \mathrm{~V}-220 \mathrm{~V} \mathrm{~Hz}$

- Operation Temp : Approx. $50 \mathrm{~W}$

- Respone Time : With in 10 seconds

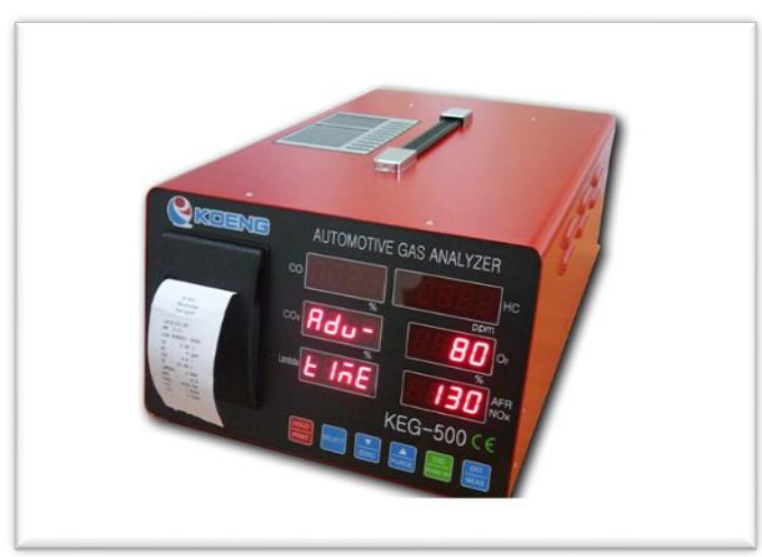

Gambar 3 Gas Analyzer

\section{HASIL DAN PEMBAHASAN}

\section{Hasil}

Data penelitian didapatkan dari hasil penelitian uji emisi yang dilakukan pada tanggal 15 Agustus 2016 di Dinas Perhubungan Kabupaten Tanah Laut menggunakan mesin sepeda motor Honda Beat 108 cc. Parameter yang diteliti adalah data emisi gas buang.

Bahan bakar yang digunakan antara lain bahan bakar premium dan bahan bakar pertalite dan menggunakan mesin sepeda motor Honda Beat dengan tahun pembuatan yang berbeda.

Variasi mesin yang digunakan adalah mesin sepeda motor dengan tahun pembuatan 2010, 2011, dan 2012, sehingga akan didapatkan besar nilai kandungan emisi gas buang pada setiap variasi bahan bakar seperti tersaji pada Tabel 4 berikut ini.

Tabel 4 Hasil Rata-rata Uji Emisi

\begin{tabular}{|l|l|l|l|l|l|}
\hline \multirow{2}{*}{$\begin{array}{l}\text { Honda } \\
\text { Tahun } \\
\text { Pembuatan }\end{array}$} & \multirow{2}{*}{$\begin{array}{l}\text { Bahan } \\
\text { Bakar }\end{array}$} & \multicolumn{4}{|c|}{ Nilai rata-rata } \\
\cline { 3 - 6 } & & $\mathrm{CO}$ & $\mathrm{HC}$ & $\mathrm{CO}_{2}$ & $\lambda$ \\
\hline 2010 & Premium & 0,140 & $1.292,60$ & 3,96 & 2 \\
\cline { 2 - 6 } & Pertalite & 0,112 & $1.283,00$ & 4,44 & 2 \\
\hline
\end{tabular}

\begin{tabular}{|l|l|l|l|l|l|}
\hline 2011 & Premium & 0,744 & 275,40 & 4,76 & 2 \\
\cline { 2 - 6 } & Pertalite & 0,652 & 136,20 & 4,96 & 2 \\
\hline 2012 & Premium & 0,372 & 407,00 & 4,18 & 2 \\
\cline { 2 - 6 } & Pertalite & 0,306 & 249,60 & 4,46 & 2 \\
\hline
\end{tabular}

Dari Tabel 4, dapat dibuat perbandingan setiap nilai Emisi Gas Buang yang diuji berupa grafik pada setiap tahun pembuatan/keluaran/produksi Kendaraan Bermotor Honda Beat $110 \mathrm{CC}$.

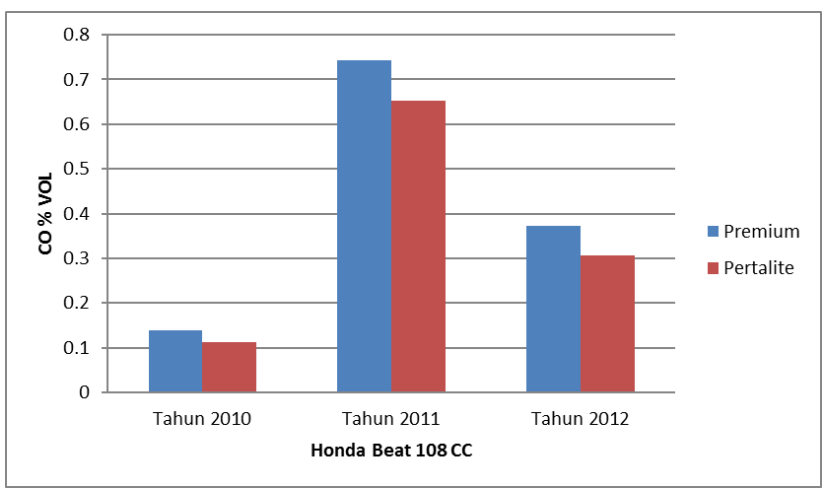

Gambar 4 Kadar CO dalam \% Vol.

Tingginya kadar CO dimungkinkan karena kandungan udara yang terlalu sedikit. Karbon di dalam bahan bakar terbakar habis dengan sempurna, maka akan terjadi reaksi sebagai berikut:

$$
\mathrm{C}+\mathrm{O}_{2} \rightarrow \mathrm{CO}_{2}
$$

Namun, jika unsur oksigen (udara) tidak cukup, maka terjadi proses pembakaran yang tidak sempurna yang menghasilkan CO seperti pada reaksi di bawah ini.

$$
\mathrm{C}+1 / 2 \mathrm{O}_{2} \rightarrow \mathrm{CO}
$$

Jumlah gas CO yang dikeluarkan oleh mesin kendaraan dipengaruhi oleh perbandingan antara udara dan bahan bakar yang dihisap oleh mesin ke dalam ruang bakar. Pada saat campuran kaya (kekurangan udara) emisi gas buang $\mathrm{CO}$ cenderung naik. Hal ini dikarenakan atom karbon (CO) yang berasal dari bahan bakar kekurangan oksigen $\left(\mathrm{O}_{2}\right)$ yang berasal dari udara untuk berikatan melalui reaksi kimia di dalam ruang bakar dan berubah menjadi karbon dioksida $\left(\mathrm{CO}_{2}\right)$.

Sedangkan pada kondisi campuran miskin (kelebihan udara) konsentrasi CO berbanding lurus dengan campuran bahan bakar dan udara yang dihisap sehingga konsentrasi CO akan turun, karena oksigen yang berasal dari udara cukup untuk memenuhi reaksi dengan karbon membentuk $\mathrm{CO}_{2}$. 


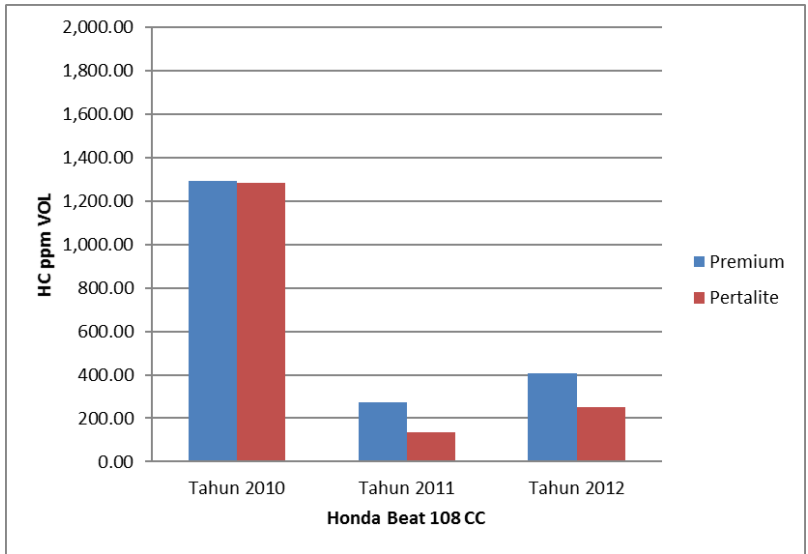

Gambar 5 Kadar HC ppm Vol

$\mathrm{HC}$ adalah bahan bakar yang belum terbakar tetapi sudah keluar bersama-sama dengan gas buang ke atmosfer. Tingginya kadar HC disebabkan oleh pembakaran yang kurang sempurna, yaitu karena kurangnya oksigen atau bahan bakar sehingga ada sebagian bahan bakar yang belum terbakar dan keluar masih dalam bentuk hidrokarbon. Pada bahan bakar pertalite kandungan $\mathrm{HC}$ terhitung sangat rendah karena bahan bakar pertalite mampu menghasilkan pembakaran lebih baik dibandingkan dengan premium.

Apabila campuran kurus (kurang bahan bakar), maka kosentrasi HC menjadi naik, hal ini disebabkan kareana kurangnya pasokan bahan bakar sehingga menyebabkan rambatan bunga api menjadi lambat dan bahan bakar akan segera keluar sebelum terbakar dengan sempurna. Sedangkan pada kondisi campuran kaya (kelebihan bahan bakar) konsentrasi HC juga akan naik akibat dari adanya bahan bakar yang belum bereaksi dengan udara yang dikarenakan pasokan udara tidak cukup untuk bereaksi menjadi sempurna, sehingga ada sebagian hidrokarbon yang keluar pada saat proses pembuangan.

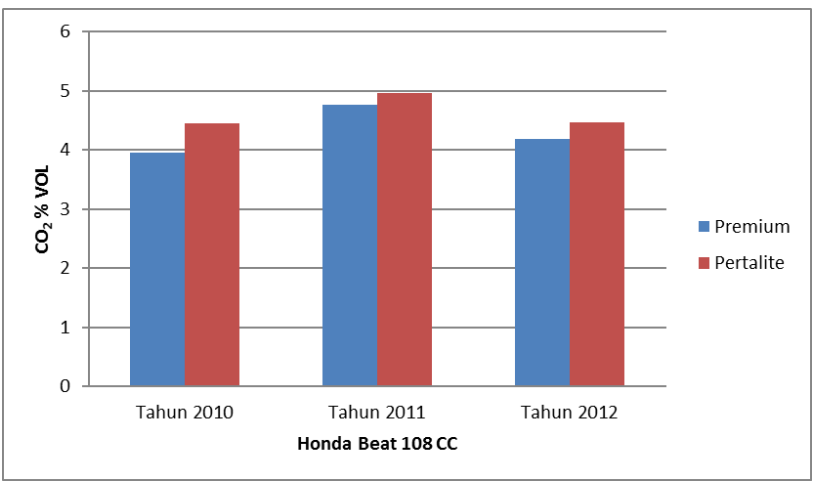

Gambar 6 Kadar $\mathrm{CO}_{2} \% \mathrm{Vol}$

Pertalite menghasilkan emisi gas buang $\mathrm{CO}_{2}$ paling tinggi, semakin tinggi kadar emisi gas buang $\mathrm{CO}_{2}$ maka semakin sempurna proses pembakaran yang terjadi diruang bakar. Pada bahan bakar pertalite dan premium, kadar $\mathrm{CO}_{2}$ pada setiap variasi tahun pembuatan bahan bakar mengalami peningkatan seiring usia tahun. Rendahnya kadar $\mathrm{CO}_{2}$ pada bahan bakar dimungkinkan karena pada kondisi idle sudut pengapian cenderung mundur, sehingga berakibat pembakaran terlambat.

Unsur yang terkandung dalam bahan bakar akan terbakar melalui pembakaran yang dihasilkan oleh bunga api atau busi. Pembakaran yang terlambat menyebabkan unsur $\mathrm{C}$ dan $\mathrm{O}$ tidak berubah menjadi $\mathrm{CO}_{2}$. Rendahnya kadar $\mathrm{CO}_{2}$ juga dimungkinkan karena AFR yang terlalu kurus atau terlalu kaya, apabila campuran terlalu banyak oksigen atau bahan bakar, maka ada sebagian unsur $\mathrm{O}$ yang tidak beriaksi dengan unsur $\mathrm{C}$ dan tidak berubah menjadi $\mathrm{CO}_{2}$.

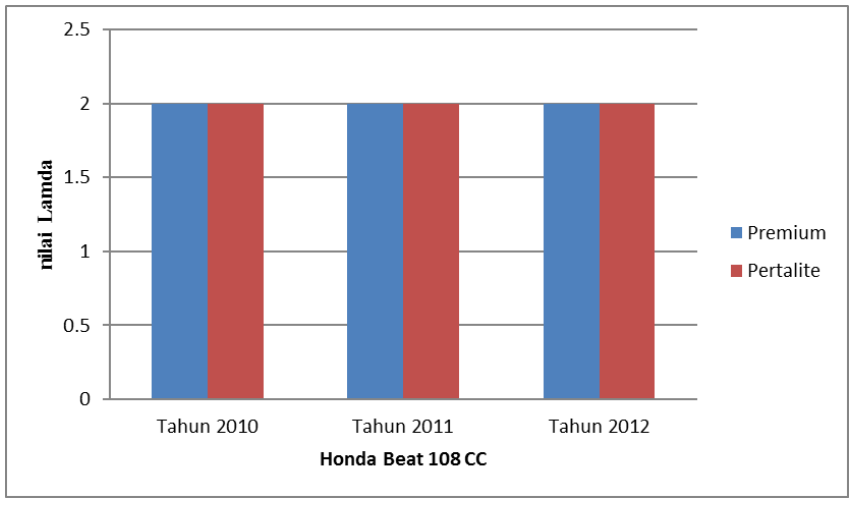

Gambar 7 Nilai Lamda

Dari Gambar 7 dapat disimpulkan nilai lambda pada bahan bakar premium nilai atau hasil yang sama yaitu memiliki lambda sama dengan 2. Kemudian pada bahan pertalite menghasilkan nilai yang sama yaitu 2 .

Nilai lambda merupakan kesimpulan proses pembakaran yang terjadi di mesin, jika lambda sama dengan 1 (satu), bearti pembakaran bahan bakar di mesin sangat efisien atau ideal, dalam artian komposisi bahan bakar dan udara benar-benar tercampur secara homogen. Tingginya nilai lambda dimungkinkan terjadi karena campuran bahan bakar terlalu kurus atau kebanyakan udara pada proses pembakaran.

\section{KESIMPULAN}

Berdasarkan pengambilan data dari perancangan steering manual pada mobil listrik dapat disimpulkan:

1. Kadar emisi gas buang ( $\mathrm{CO}, \mathrm{HC}, \mathrm{CO}_{2}$, dan $\left.\lambda\right)$ menujukkan bahwa pada bahan bakar pertalite adalah yang paling baik, ini dikarenakan campuran bahan bakar pertalite lebih homogen dan RON lebih tinggi dibandingkan premium.

2. Keunggulan menggunakan bahan bakar pertalite adalah peningkatan perbaikan kadar emisi gas buang rata-rata sebesar $18 \%$. 


\section{DAFTAR PUSTAKA}

[1] Winarno, J. 2014. Studi Emisi Gas Buang Kendaraan Bermesin Bensin Pada Berbagai Merk Kendaraan dan Tahun Pembuatan.

[2] Raharjo W, D, dan Karnowo. 2008. Mesin Konversi Energi. Semarang: Uni Press.

[3] Prihandana R, K. Noerwijayanti, P.G Adinurani, D. Setyaningsih, S.Setiadi dan R. Handoko. 2008. Bioethanol Ubi Kayu Bahan Bakar Masa Depan. Jakarta: Agromedia.

[4] Fauji, M. 2015. Pengaruh Bioetanol Terhadap dan Emisi Gas Buang Pada Sepeda Motor Empat Tak Satu Silinder Berbahan Bakar Premium.

[5] Hardjono, A. 2001. Teknologi Minyak Bumi. Yogyakarta : Gadjah Mada.

[6] Kusminingrum, Nanny, dan G. Gunawan. 2008. Polusi Udara Akibat Aktivitas Kendaraan Bermotor di Jalan Perkotaan Pulau Jawad an Bali.

[7] Lingkungan Hidup. 2006. Ambang Batas emisi Gas Buang Kendaraan Bermotor Lama. Permen LH No. 05 .

[8] Yahya, Wachid. 2015. Variasi Penggunaan Ionizer Dan Jenis Bahan Bakar Terhadap Kandungan Gas Buang Kendaraan. Jurnal AUTINDO Politeknik Indonusa Surakarta Vol. 1 No.2. 